ческая экспертиза, несанкиионированное вмешательство в работу информационнотелекоммуникаиионных систем.

\title{
PLACE OF FORENSIC SCIENCE IN THE CYBERTHREATS PREVENTION SYSTEM IN FIELD OF A UKRAINIAN INFORMATION SECURITY
}

\author{
Rusetskyi A. A.
}

Theoretical developments and practical experience of countering cyberthreats in the field of information security of Ukraine are analyzed. It is determined that the crime prevention in the field of information security is structurally composed of several stages. They include: search for primary information on criminal activity in the information field; prevention of cybercrime; detection of illegal actions in the field of information security while operative investigative activities and pre-trial investigation of criminal proceedings. The most common illegal actions in the field of information security is unauthorized tampering in the work of information and telecommunications systems. In order to identify these crimes during operative investigative activities within the criminal procedure operational officers and investigators must possess methods of detecting specified illegal actions and objects that can be subject to research. Theoretical bases of recommendations for search, detection, fixation and seizure of these facilities should be appropriate criminalistic methods. Legal basis for the formation of these methods should be legislative and departmental regulatory acts. However, in a number of normative legal acts related to ensuring cybersecurity in Ukraine, there are inconsistencies in the conceptual apparatus, especially with regard to specific object types of forensic science, signs of unauthorized tampering in the work of information and telecommunications systems. It was found out that counteraction to cyberthreats in the field of information security in Ukraine should be based on a system integrated approach to use of all structural elements, coordination of its subject activities including forensic experts. The theoretical basis for the formation of a system integrated approach to crime prevention in this field is the implementation of research on research of theoretical applied branches of jurisprudence: criminalistics, theory of forensic science, theory of operative investigative activities.

Keywords: cyberthreats, information security, harmful software, crime prevention, computer forensic examination, unauthorized tampering in the work of information and telecommunication systems.

DOI: https://doi.org/10.32353/khrife.2018.30 УДК 343.98

H. $\boldsymbol{C}$. Філіпенко, провідний науковий співробітник Харківського НДІСЕ, кандидат юридичних наук, доцент E-mail: filipenko_natalia@ukr.net

\section{ІНФОРМАЦЙНІ СИСТЕМИ В СУДОВО-ЕКСПЕРТНІЙ ДІЯЛЬНОСТІ}

(оглядова стаття)

Розглянуто теоретичні проблеми використання інформаційних систем у судово-експертних дослідженнях. Проаналізовано позиції та підходи вчених до визначення поняття й сутності теоретичної категорії «інфор-

(C) Філіпенко Н. Є., 2018 
мація». За результатами узагальнення досвіду роботи судово-експертних установ України, статистичних даних, матеріалів сучасної експертної практики та фахових літературних джерел наведено авторське визначення інформачійної діяльності судового експерта. Запропоновано заходи, спрямовані на підвищення ефективності використання інформащії в судовоекспертних дослідженнях.

Ключові слова: інформаційні системи, судово-експертні дослідження, інформаційні технології, інформаційне забезпечення, експертні системи, криміналістична інформачія.

Сучасний етап розвитку судової експертизи характеризується високим динамізмом, активним впливом на іiі розвиток науково-технічного прогресу, цілеспрямованим і активним пошуком ефективних шляхів удосконалення експертної практики на фундаментальній теоретичній основі. До основних особливостей судових досліджень на сучасному етапі можна віднести їх високу наукоємність, використання досягнень кібернетики, які, інтегруючись у криміналістику та судову експертизу, виступають каталізатором подальшого розвитку іiї традиційних засобів і методів на основі досягнень природничих, технічних і гуманітарних наук. Чималий вплив інформатики на судово-експертну практику зумовлений, по-перше, оптимізацією пізнавальних процесів; по-друге, подальшою автоматизацією експертної діяльності; по-третє, раціоналізацією прийнятих рішень 3 використанням інформаційних систем тощо. Кібернетика внесла не тільки досить продуктивний інформаційний підхід, який дозволив розширити можливості майже всіх видів експертиз, а й відкрила шляхи для автоматизації експертизи. Активно ведеться розроблення спеціальних інформаційних систем, що містять дані про ідентифікаційне й діагностичне значення ознак, про властивості більшості об'єктів експертного дослідження, про алгоритмічні та евристичні способи вирішення експертних завдань. Комп'ютерна техніка дозволяє якнайширше використовувати ці банки даних експертам, які працюють в експертній установі та навіть проводять дослідження на місці події. У теорії й практиці експертизи застосовується системний підхід, прийоми структурного та системного аналізів. Одним із перспективних шляхів удосконалення процесів ідентифікації $€$ використання теорії інформації. Інформаційний підхід дозволяє: окреслити шляхи аналізу і оцінити втрати інформації про ідентифікаційні ознаки на різних етапах їх відображення; використовувати математичний апарат для аналізу не тільки систематичних і загальних, а й також випадкових і локальних спотворень ознак та інших втрат інформації на основі єдиного, універсального до них підходу; зменшити неточності уявлень експертів про істоту ознак.

Інформація відіграє важливу роль у діяльності людини, яка в спілкуванні користується мовою та більшою мірою керується знаннями. Тому держава сприяє розвитку української мови як основного інструмента перетворення накопичених людством знань в інформаційний ресурс. 
Попри насичену практику застосування інформаційних потоків у інтелектуальній діяльності сучасної людини та широку теоретичну розробку цієї наукової категорії, на сьогодні немає сталої дефініції поняття «інформація». Це пояснюється, у першу чергу, багатоманітністю сфер застосування інформації; по-друге, багатовекторністю інформаційних потоків; по-третє, великою кількістю операторів, які обмінюються (поширюють) відомості; по-четверте, бурхливим розвитком сучасних комунікаційних зв'язків і технологій тощо. Також на сутність категорії, що розглядається, сильно впливає відсутність єдиної уніфікованої наукової мови (тобто поняття використовується в межах тієї науки, у якій застосовується). Фахівців уже не задовольняє старе визначення поняття інформації, їм необхідні більш конкретні ії ознаки.

Існує багато визначень інформації, у кожному з яких відображені або специфіка галузі знань, у якій використовується певне визначення, або особливості професійної діяльності особи, що дала або запропонувала зазначене визначення, або просто його персональний смак і термінологічні схильності ${ }^{1}$.

Нормативно-правове визначення терміна «інформація» зустрічається в багатьох чинних актах, значну частину з яких складають закони України. Однак лише в трьох чинних законах міститься саме визначення категорії «інформація». Зокрема, це закони України «Про інформацію», «Про захист економічної конкуренції», «Про телекомунікації», ДСТУ 2392-94 «Інформація і документація. Базові поняття. Терміни та визначення».

Відповідно до ст. 1 Закону України «Про інформацію» під нею розуміється документовані або публічно оголошені відомості про події та явища, що відбуваються в суспільстві, державі та навколишньому природному середовищі ${ }^{2}$.

У Законі України «Про захист економічної конкуренції» інформація - це відомості в будь-якій формі й вигляді та збережені на будь-яких носіях (у тому числі листування, книги, помітки, ілюстрації (карти, діаграми, рисунки, схеми тощо), фотографії, голограми, кіно-, відео-, мікрофільми, звукові записи, бази даних комп'ютерних систем або повне чи часткове відтворення їх елементів), пояснення осіб та будь-які інші публічно оголошені чи документовані відомості ${ }^{3}$.

У Законі України «Про телекомунікації» зазначено, що інформація - це відомості, подані у вигляді сигналів, знаків, звуків, рухомих або нерухомих зображень чи в інший спосіб (ст. 1) ${ }^{4}$.

${ }^{1}$ Коган В. 3. Теория информационного взаимодействия: философско-социологические очерки. Новосибирск : Изд-во Новосибирск. ун-та, 1991. С. 114-115.

2 Про інформацію : Закон України від 02.10.1992 № 2657-XII. База даних «3aконодавство України». URL: http://zakon3.rada.gov.ua/laws/show/2657-12.

3 Про захист економічної конкуренції : Закон України від 11.01.2001 № 2210-III. Tам само. URL: http://zakon5.rada.gov.ua/laws/show/2210-14.

4 Про телекомунікації : Закон України від 18.11.2003 № 1280-IV. Там само. URL: http://zakon2.rada.gov.ua/laws/show/1280-15. 
У ДСТУ 2392-94 інформація - це знання, що розглядаються в аспекті комунікації ${ }^{1}$.

Аналізуючи термінологію наведених нормативно-правових документів, незважаючи на нетотожність тлумачення цього терміна, можна відмітити низку спільних ознак, головною із яких $є$ те, що вітчизняний законодавець під інформацією вважає насамперед «відомості». Тому можна стверджувати, що інформація - це в першу чергу будь-які відомості (іх сукупність), отримані із зовнішнього середовища, збережені в будь-якій формі й вигляді на будь-яких носіях і подані в будь-який спосіб для усунення невизначеності.

Коли йдеться про інформацію, то мають на увазі такі іiі властивості: інформація достовірна, якщо вона не спотворює істинного стану явищ, процесів, фактів, подій; інформація повна, якщо їі достатньо для розуміння та прийняття обгрунтованих рішень; інформація чітка й зрозуміла, якщо вона виражена мовою, якою спілкуються (яку розуміють) ті, для кого вона призначена; якість інформації - це сукупність властивостей, що зумовлюють можливості iї використання для задоволення визначених згідно з іiі призначенням потреб; цінність - комплексний показник якості інформації, iiï міри на прагматичному рівні, яка визначає іiі корисність, цінність для прийняття певного рішення; адекватність інформації - це певний рівень відповідності, що створюється за допомогою отриманої інформації, образу реального об'єкта, процесу, явища тощо ${ }^{2}$.

Досліджуючи властивості інформації, слід підкреслити специфіку правового регулювання суспільних відносин щодо інформації, тобто ії юридичні властивості.

По-перше, фізична невідчужуваність інформації полягає в тому, що інформація не здатна відчужуватися від людини - іiї носія. У більш широкому тлумаченні, ця властивість може бути перенесена й на юридичних осіб, суб'єктів інформаційних відносин. Під час передавання (поширення) інформації від однієї особи до другої вона може залишатися в обох, навіть виробник інформації здебільшого зберігає комплекс авторських прав на інформацію.

По-друге, необхідність відособлення інформації передбачає, що для залучення іiі у врегульований правом обіг інформація має бути відокремлена від іiі виробника способом подання iï у формі сигналів, знаків, звуків, рухомих або нерухомих зображень чи іншим способом і в такій формі передана іншим суб'єктам інформаційних відносин.

По-трете, незалежність прав на інформацію та на ії матеріальний носій юридична властивість інформації, що захищена правом інтелектуальної власності, полягає в тому, що інформація на матеріальних носіях одночасно

\footnotetext{
1 ДСТУ 2392-94 «Інформація і документація. Базові поняття. Терміни та визначення». Видання офіційне. Київ : Мінекономрозвитку, 1994 (зі змінами та доповн.).

2 Інформаційні технології в юридичній діяльності: базовий курс : навч. посібник / О. В. Співаковський, М. І. Шерман, В. М. Стратонов, В. В. Лапінський. Херсон : ХДУ, 2012. С. 17.
} 
є інформацією (змістом) і матеріальним носієм. У більш загальному розумінні можна зазначити, що право на інформацію та право власності на матеріальний носій інформації не залежать одне від одного. Відчуження матеріального носія не означає відчуження права на інформацію і навпаки.

По-четверте, здатність до тиражування - це властивість інформації, яка безпосередньо пов'язана з такою іiі характеристикою, як невичерпність. Ця властивість $є$ ключовою для правового регулювання діяльності щодо розповсюдження інформації, адже останню можна копіювати (тиражувати) необмежену кількість разів, і при цьому вона не зменшується в обсязі й не втрачає своїх споживчих якостей ${ }^{1}$.

Що стосується форм подання інформації, зазначимо, що інформацію можуть містити повідомлення, які передаються у двох формах - аналоговій і дискретній. Аналогова, або безперервна форма подання повідомлення - це значення певної фізичної величини, що характеризує процес, який не має перерв або проміжків (наприклад, швидкість автомобіля на визначеній ділянці шляху). Дискретна форма подання повідомлення - це послідовність символів, яка характеризує переривчастий ланцюг подій (наприклад, кількість досліджень, що проводилися експертом за різний проміжок часу).

Стосовно наукового визначення цього поняття підкреслимо, що одним із перших, хто дослідив сутність впливу інформації на розвиток суспільства та запропонував визначення інформації, був американський математик Н. Вінер. У своїх роботах він наголошував, що інформація - це визначення змісту, одержаного із зовнішнього світу в процесі нашого пристосування до нього та пристосування до нього наших почуттів. Процес одержання, використання інформації $є$ процесом нашого пристосування до випадковостей зовнішнього середовища й нашої життєдіяльності в зовнішньому середовищі ${ }^{2}$. Застосування загальних законів теорії філософії дозволило пізнати природну сутності інформації. Відомий учений-філософ В. А. Штоф під інформацією розумів певну характеристику відображення внаслідок того, що відображення є загальною властивістю, атрибутом матерії й завжди характеризується організованістю. Інформація, зазначав він, виступає як визначена характеристика відображення, унаслідок того, що відображення $є$ загальним атрибутом матерії та постійно характеризується організованістю3 .

Проаналізувавши наведені поняття, не можемо не погодитися із фахівцями, що саме категорія відображення є тим ключем, що дозволив відкрити природу інформації. Конкретизація змісту привела до одночасного розширення обсягу поняття «інформація» та стала характеризувати не тільки аспект людського спілкування, а й комунікативні явища в техніці, біологічних та інших процесах. Інформація проектується на «екран знань», пов'язується

\footnotetext{
1 Інформаційне право. URL: http://studies.in.ua/inform-pravo-shporu/2502yuridichn-osoblivost-nformacyi.html.

2 Винер Н. Кибернетика и общество. Москва : Тайдекс Ко, 2002. С. 31.

3 Штоф В. А. Моделирование и философия. Ленинград : Наука, 1996. С. 119120.
} 
з такими поняттями, як ерудиція та творчі здібності особи, що надзвичайно важливо для прийняття управлінського рішення ${ }^{1}$.

Інформація розглядається як стратегічний продукт, вона є основою управлінської діяльності, відображає не тільки умови існування, якість, закономірності, особливості об’єкта, функціонування суб'єкта, але також систему управління в цілому, з їі елементами зокрема ${ }^{2}$.

У теорії точних наук, зокрема математиці, існує інший, відмінний від філософського, підхід до розуміння природи інформації. Під інформацією в кібернетиці розуміють будь-яку сукупність сигналів, впливів чи відомостей, які деяка система вбирає від навколишнього середовища (вхідна інформація), віддає в навколишнє середовище (вихідна інформація) чи, зрештою, зберігає в собі (внутрішня, внутрішньосистемна інформація) ${ }^{3}$.

У теорії правничих наук дослідження правових явищ тісно пов'язане 3 розвитком окремого загальнонаукового інформаційного підходу,, унаслідок якого сформувався новий напрям, що поєднує предмет науки криміналістики з інформаційними процесами 5 . При цьому деякі науковці поняття «інформація» ототожнюють 3 такими поняттями, як «дані», «відомості», «повідомлення», «знання» тощо. Завдяки цьому в теорії правових наук 3'явилися та поширилися такі поняття, як «правова/юридична» ${ }^{6}$, «доказова» ${ }^{7}$, «орієнтуюча» ${ }^{8}$, «криміналістична» ${ }^{9}$, «оперативно-розшукова» ${ }^{10}$ інформація тощо.

1 Урсул А. Д. Проблема информации в современной науке. Москва : Наука, 1975. C. 114.

2 Пілюков В. О. Використання інформаційних систем в експертних підрозділах МВС України : дис. ... канд. юрид. наук : 12.00.09. Київ, 2009. С. 19.

3 Домброускайте О. К., Игнатьева Ю. Я., Ланиман Р. М. Анализ некоторых результатов использования ЭВМ для дифференциации близких по характеристикам движений почерковых объектов. Кибернетика и судебная экспертиза. Вильнюс : НИИСЭ, 1966. Вып. 2. С. 190.

4 Лукашевич В. Г. Криминалистическая теория общения: постановка проблемы, методика исследования, перспективы использования. Киев : Изд-во Укр. акад. внутр. дел, 1993. 194 с.

5 Салтевский М. В. Идентификация и информация. Правоведение. 1965. № 3. C. 84-90.

6 Інформаційні технології в юридичній діяльності.

7 Белкин А. Р. Теория доказывания : науч.-метод. пособие. Москва : НОРМА, 1999. C. 173.

8 Пацкевич А. П. Автоматизированные системы как элемент структуры информационно-криминалистического обеспечения раскрытия и расследования преступлений. Пробл. криминалистики : сб. науч. тр. Минск : Академия МВД Респ. Беларусь, 2003. С. 182.

9 Криміналістика : підручник / П. Д. Біленчук, О. П. Дубовий, П. Ю. Тимошенко, М. В. Салтевський. Київ : НАВСУ, 1997. С. 143-146.

${ }^{10}$ Коваленко Е. Д. Використання оперативної інформації як підстави для застосування заходів процесуального примусу у кримінальному судочинстві : автореф. дис. ... канд. юрид. наук : 12.00.09. Київ, 2007. 20 с. 
Інформація в юридичній діяльності - це відомості про навколишній світ (об’єкти, явища, події, процеси тощо), які зменшують існуючу невизначеність, неповноту знань, які можна передавати усним, письмовим або іншим способом, а також за допомогою умовних сигналів, технічних і обчислювальних засобів тощо ${ }^{1}$. Інформація про певний об'єкт, явище виникає тоді, коли відбувається інтерпретація даних, отриманих у вигляді повідомлення про стан об’єкта. М. В. Салтевський інформацію, що обертається у сфері розслідування злочинів, називає криміналістичною і звертає увагу на їі специфічні ознаки: вона використовується сукупно з іншими видами інформації, утворюючи систему, яка дозволяє встановлювати обставини події злочину; в інформаційній системі вона має домінуюче значення; слідчий отримує ії̈ завдяки проведенню слідчих дій, а також оперативно-розшукових заходів ${ }^{2}$.

Інформація у сфері судово-експертної діяльності є похідною від правової інформації, але має декілька індивідуальних особливостей. Виходячи з цього, під інформачією у сфері судово-експертної діяльності розуміється сукупність відомостей щодо матеріальних об'єктів, фактів, явищ і процесів, які містять дані про обставини злочинної діяльності та досліджуються експертом із використанням спеціальних знань.

Незважаючи на те, що саме поняття «інформація» належить до абстрактних, проявляється воно завжди в матеріально-енергетичній формі, зокрема у вигляді сигналів ${ }^{3}$. Підтримуючи міркування В. О. Пілюкова із цього приводу, наголошуємо, що сигнал може мати різну фізичну природу, в інформаційному процесі він виконує функцію переносника інформації від іiі джерела до приймача й далі до адресата.

Підгрунтям для дослідження інформаційних процесів у судовій експертизі є положення нової галузі знань - інформаційної епістемології, яка розглядає знання з позиції перероблення й перетворення інформації (епіс-

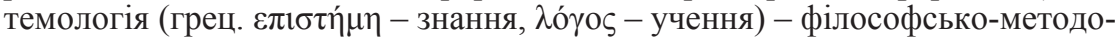
логічна дисципліна, у якій досліджується знання як таке, його будова, структура, функціонування та розвиток. Термін уведений і активно застосовувався в англо-американській філософії XX ст. Традиційно ототожнюється з теорією пізнання. Однак у некласичній філософії може бути зафіксована тенденція до розрізнення епістемології та гносеології, що грунтується на вихідних категоріальних опозиціях. Якщо гносеологія розгортає свої уявлення навколо опозиції «суб'єкт - об'єкт», то для епістемології базовою є опозиція «об'єкт - знання»)".

Для судової експертизи інтерес мають питання застосування інформаційних систем і процеси перетворення інформації, які є обов'язковою умовою її функціонування. Залежно від конкретних умов, особливостей вихід-

\footnotetext{
1 Інформаційні технології в юридичній діяльності. С. 17.

2 Салтевский М. В. Криминалистика. В современном изложении юристов. Харьков : Рубикон, 1996. С. 142-143.

3 Пілюков В. О. Зазнач. твір. С. 24.

4 Вікіпедія - вільна енциклопедія. URL: https://uk.wikipedia.org/wiki/Епістемологія.
} 
ної інформації, кількості їі проміжних приймачів і споживачів, процес передачі інформації, іiі рух від джерела до кінцевого адресата може бути багатоступеневим; інформаційний сигнал і кожен із проміжних елементів цього ланцюга можуть змінювати свою фізичну природу й характер пристроїв, що використовуються. У зв’язку з цим у загальній проблематиці оптимізації інформаційних процесів дуже актуальними є такі питання, як ізоморфність (взаємна однозначність) інформації і їі сигналу, повнота й об'єктивність передачі, можливість (здатність) її сприйняття приймаючим суб'єктом або технічним пристроєм ${ }^{1}$.

Інформаційні процеси - послідовна зміна стану та/або уявлення про інформацію в результаті дій, які з нею можна виконувати. У загальному вигляді схему передачі інформації можна уявити таким чином: джерело інформації - передача інформації (канал передачі) - приймач інформації.

Стаття 14 Закону України «Про інформацію» визначає, що основними видами інформаційної діяльності є одержання, використання, поширення та зберігання інформації ${ }^{2}$. Одержання інформації - це набуття, придбання, накопичення відповідно до чинного законодавства України документованої або публічно оголошуваної інформації громадянами, юридичними особами або державою. Використання інформації - це задоволення інформаційних потреб громадян, юридичних осіб і держави. Поширення інформації - це розповсюдження, обнародування, реалізація у встановленому законом порядку документованої або публічно оголошуваної інформації. Зберігання інформації - це забезпечення належного стану джерел інформації (документів, відомостей) та їх матеріальних носіїв.

На підставі відомостей, наведених у нормативно-правових актах, фахових літературних джерелах і матеріалах проведених досліджень, сформулюємо визначення інформаційної діяльності судового експерта. Отже, під інформаційною діяльністю судового експерта розуміється заснований на законах і підзаконних нормативних актах комплекс дій, спрямованих на одержання інформації стосовно об 'єктів дослідження, наданих експерту для проведення судової експертизи, шляхом здійснення сукупності інформаційно-пошукових, інформаційно-комунікативних та інформаційно-аналітичних заходів і уникнення дезінформації з метою складання об' єктивного, неупередженого та компетентного висновку.

Здійснюючи інформаційну діяльність, судовий експерт є вільним у виборі методів дослідження, методик проведення судових експертиз, а також нормативно-правових актів і нормативних документів (міжнародних, національних та галузевих стандартів, технічних умов, правил, норм, положень, інструкцій, рекомендацій, переліків тощо), а також науково-технічної, довідкової літератури, програмних продуктів тощо. Тобто у свідомості експерта проходить складна робота, заснована на безлічі сигналів, причому кожен із них має свою індивідуальну характеристику. При цьому швидкість проходження нервового імпульсу з нейрона в нейрон може змінюватися

Пілюков В. О. Зазнач. твір. С. 25.

2 Про інформацію : Закон України від 02.10.1992 № 2657-XII. 
залежно від існуючих обставин. До того ж, здійснюючи професійну діяльність, експерт опрацьовує значний обсяг різнорідної, часто неповної інформації та приймає рішення, не стикаючись із проблемою функціональних блоків. У комп’ютері передача сигналів заснована на електричних імпульсах і абсолютно сталому, логічному та повному інформаційному масиві. За наявності певних «прогалин» машина не здатна обробити всі дані та надати обгрунтований аналіз відомостей.

Завершальним етапом інформаційної діяльності судового експерта $\epsilon$ процес подання інформації та прийняття ним рішення. Сутність цієї стадії складається з демонстрації різного роду зображень, що містять характеристики вихідної інформації. Вони можуть бути як якісними, так і кількісними, що досягається використанням різних технічних пристроїв, зокрема індикаторів (цифрових, графічних реєструючих приладів), дисплеїв, які на сьогодні одержали більше поширення. Вони дозволяють створити інформаційну людино-машинну систему, у якій є можливість використовувати ЕОМ у так званому діалоговому режимі ${ }^{1}$.

Особливу стадію інформаційної діяльності судового експерта складає процес збереження інформації, під яким розуміється здійснення комплексу дій щодо обмеження доступу до підсумкової інформації сторонніх осіб (ії втрати, псування) і своєчасного отримання особами, щэо призначили (замовили) експертизу.

Позитивний вплив використання інформатики в експертній практиці досягається, по-перше, завдяки раціоналізації пізнавальних процедур; подруге, через покращення автоматизації діяльності; по-третє, шляхом оптимізації прийняття складних рішень з використанням систем, заснованих на базі знань.

Таким чином, інформаційне забезпечення судово-експертної діяльності $\epsilon$ системою науково організованого та безперервного процесу відбору, підготовки та видачі систематизованої науково-технічної інформації, необхідної для вирішення судово-експертних завдань.

\section{ИНФОРМАЦИОННЫЕ СИСТЕМЫ В СУДЕБНО-ЭКСПЕРТНОЙ ДЕЯТЕЛЬНОСТИ}

\section{Филипенко Н. Е.}

Рассмотрены теоретические проблемы использования информационных систем в судебно-экспертных исследованиях. Приведены основные особенности судебноэкспертных исследований на современном этапе, к которым можно отнести их высокую наукоемкость, использование достижений кибернетики, которые, интегрируясь в криминалистику и судебную экспертизу, выступают катализатором дальнейтего развития ее традиционных средств и методов на основе достижений естественных, технических и гуманитарных наук. Большое влияние информатики на судебно-экспертную практику обусловлено оптимизацией познавательных проиеессов, дальнейшей автоматизацией экспертной деятельности, рационализацией

\footnotetext{
${ }^{1}$ Пілюков В. О. Зазнач. твір. С. 28.
} 
принятых решений с использованием информационных систем и т. п. Несмотря на насыщенную практику применения информационных потоков в интеллектуальной деятельности современного человека и широкую теоретическую разработку этой научной категории, сегодня нет постоянной дефиниции понятия «информачия». Это объясняется разнообразием сфер применения информации, многовекторностью информационных потоков, большим количеством операторов, обменивающихся сведениями; бурным развитием современных коммуникационных связей и технологий. Информация в сфере судебно-экспертной деятельности является производной от правовой информации, но имеет ряд индивидуальных особенностей. Исходя из этого, под информацией в сфере судебно-экспертной деятельности понимается совокупность сведений о материальных объектах, фактах, явлениях и процессах, которые содержат данные об обстоятельствах преступной деятельности и исследуются экспертом с применением специальных знаний. На основании анализа мнений ученых сформулирована дефиниция информационной деятельности судебного эксперта, под которой понимается основанный на законах и подзаконных нормативных актах комплекс действий, направленных на получение информации об объектах экспертного исследования, путем осуществления совокупности информационно-поисковых, информационно-коммуникативных и информационно-аналитических мероприятий с иелью составления компетентного заключения.

Ключевые слова: информационные системы, судебно-экспертные исследования, информационные технологии, информационное обеспечение, экспертные системы, криминалистическая информация.

\section{INFORMATION SYSTEMS IN FORENSIC EXPERT ACTIVITY}

\section{Filipenko N. Ye.}

This article is devoted to the consideration of theoretical problems of using information systems in forensic science research. Main features of forensic science research at the present stage are carried out that can be attributed to their high research intensity, use of cybernetics achievements which integrating into criminalistics and forensic science act as a catalyst for further development of its traditional means and methods based on achievements of natural, technical and human sciences. The great influence of informatics on forensic expert practice is due to optimization of cognitive processes; further expert activity automation; rationalization of decisions made using information systems, etc. Despite the extensive practice of applying information flows in the intellectual activity of the modern human and broad theoretical development of this scientific category; today there is no constant definition of the "information" concept. This is explained by a variety of the application of information areas, multidirectional nature of information flows, there are a large number of operators exchanging information, rapid development of modern communication connections and technologies. Information in the field of forensic expert activity is derived from legal information but has a number of individual features. Proceeding from this, the information in the field of forensic expert activity is understood as a information collection about material objects, facts, phenomena and processes containing data about criminal activity circumstances and are investigated by an forensic expert using special knowledge. On the basis of the analysis of scientific opinions the definition about information activity of forensic expert is formulated, which is understood a complex of acts based on laws and regulations, aimed at obtaining information about 
objects of expert research by implementing a set of information-research, informationalcommunicative and informational-analytical activities with the purpose of compiling a competent conclusion.

Keywords: information systems, forensic science researches, information technologies, information support, expert systems, criminalistic information.

DOI: https://doi.org/10.32353/khrife.2018.31

УДК 343.98:05

C. Г. Гаспарян, старший науковий співробітник Харківського НДІСЕ

E-mail: hniise@ hniise.gov.ua

\section{ШЛЯХИ ПІДВИЩЕННЯ ЯКОСТІ ПІДГОТОВКИ КАДРІВ ДЛЯ СУДОВО-ЕКСПЕРТНИХ УСТАНОВ МІНІСТЕРСТВА ЮСТИЦЇ̈ УКРАЇНИ}

Розглянуто питання необхідності реформування й удосконалення якості підготовки та підвищення кваліфікаиії кадрів для судово-експертних установ Міністерства юстииї України. Викладено історичні аспекти щฺодо створення аспірантури в кабінетах науково-судової експертизи в Украӥні. Запропоновано шляхи вирішення проблем, пов 'язаних із підготовкою наукових кадрів вищої кваліфікачії.

Ключові слова: підготовка кадрів, система якості, судова експертиза, судово-експертні установи, судовий експерт.

Динамічний розвиток судово-експертної діяльності в Україні, упровадження в практику судово-експертних установ Міністерства юстиції нових технологій, а також зростання потреб до якості проведення судових експертиз визначають актуальність завдань щодо вдосконалення підготовки наукових кадрів вищої кваліфікації для потреб судово-експертної діяльності. Нині питання підготовки фахівців судово-експертних установ Міністерства юстиції України та фахівців, які не $є$ працівниками цих установ, а також підготовки наукових кадрів вищої кваліфікації є одним із пріоритетних при вирішенні завдань реформування судової експертизи, спрямованих на іiі подальший розвиток і підвищення якості експертних досліджень.

Професійні та кваліфікаційні вимоги, що ставляться до судового експерта, викладено в Законі України «Про судову експертизу»1. Так, у ст. 10 цього Закону зазначено, що судовими експертами можуть бути особи, які мають необхідні знання для надання висновку з досліджуваних питань. Судовими експертами державних спеціалізованих установ можуть бути фахівці, які мають відповідну вищу освіту, освітньо-кваліфікаційний рівень не нижче спеціаліста, пройшли відповідну підготовку та отримали кваліфікацію судового експерта з певної спеціальності. До проведення судових

Про судову експертизу : Закон України від 25.02.1994 № 4038-XII. Відом. Верхов. Ради України. 1994. № 28. Ст. 232.

(C) Гаспарян С. Г., 2018 